\title{
ARTICLE
}

\section{Halogenated isophthalamides and dipicolineamides: the role of the halogen substituents on the anion binding properties}

Received 00th January 20xx, Accepted 00th January 20xx DOI: $10.1039 / x 0 x x 00000 x$

\author{
Giacomo Picci, ${ }^{a}$ Carla Bazzicalupi, ${ }^{b}$ Simon J. Coles, ${ }^{c}$ Paola Gratteri, ${ }^{d}$ Francesco Isaia, ${ }^{\text {a } V i t o ~ L i p p o l i s, ~}{ }^{a}$ \\ Riccardo Montis, ${ }^{\text {as }}$ Sergio Murgia, ${ }^{a}$ Alessio Nocentini, ${ }^{d}$ James B. Orton, ${ }^{c}$ and Claudia Caltagirone*a
}

\section{Introduction}

The development of neutral receptors for anion recognition has been a fundamental topic in the field of Supramolecular Chemistry in the last 20 years. ${ }^{1-5}$

It is well known that in Nature proteins can bind anions through their amide linkages that can work both as hydrogen bond donors (via the $\mathrm{NH}$ groups) and hydrogen bond acceptors (via the $\mathrm{C}=\mathrm{O}$ groups). Therefore, among the various classes of neutral receptors, those containing one or more amide moieties have attracted a great attention. In particular, the pioneering work of Crabtree and Smith at the end of the '90s demonstrated that isophthalamides are a promising class of receptors which are able to bind anions both in solution and in the solid state when adopting a syn-syn conformation. ${ }^{6,7}$ Since then, the isophthalamide motif and its pyridine analogous have been adopted in the design of both acyclic and

a. Dipartimento di Scienze Chimiche e Geologiche, Universita'degli Studi di Cagliari, S.S. 554 Bivio per Sestu, 09042 Monserrato (CA), Italy Email: ccaltagirone@unica.it b. Dipartimento di Chimica 'Ugo Schiff' Via della Lastruccia, 3-13 50019 SESTO FIORENTINO (FI), Italy.

chemistry University of Southampton Highfield Southampton SO17 1BJ (UK).

$\S$ Current address: School of Chemical Engineering and Analytical Science, The University of Manchester, The Mill, Sackville Street, Manchester M1 3AL (UK) Email: riccardo.montis@manchester.ac.uk.

d. Department of NEUROFARBA, Section of Pharmaceutical and Nutraceutical Sciences, Laboratory of Molecular Modeling Cheminformatics \& QSAR, University of Florence, Polo Scientifico, Via U. Schiff 6, 50019 Sesto Fiorentino, Firenze, Italy.

Electronic Supplementary Information (ESI) available: [Stack plots and NMR fitting, discussion on theoretical calculations, details on crystallization experiments and crystal packing for structures $\mathbf{L} \mathbf{1}, \mathbf{L 2}, \mathbf{L} \mathbf{4}, \mathbf{L} \mathbf{5}$ and $\mathbf{L 6}^{2-}(\mathrm{TBA})_{2} \cdot \mathrm{H}_{2} \mathrm{O}$ ]. See DOI: $10.1039 / x 0 x x 00000 x$ macrocyclic neutral systems for anion binding and transport and for the development of molecular architectures able to perform a selective host-guest interaction via $\mathrm{H}$-bonds formation. ${ }^{8-17}$ We have also recently contributed to this topic developing a unique example of a pH switchable isophthalamide capable of binding fluoride via hydrogen bonding. ${ }^{18}$

Along with $\mathrm{H}$-bonds, other weak interactions could contribute to the stabilization of anion adducts with neutral receptors, thus determining the selectivity of the molecular recognition processes. For example, halogen bonds $D-X \cdots B(X B)$, highly directional supramolecular interactions between an electrophilic halogen containing species ( $D-X$ donor) and a Lewis base (B acceptor) can drive specific supramolecular arrangements cooperatively with $\mathrm{H}$-bonds ${ }^{19-21}$. In the case of anion-binding, XB are particularly attractive for the electronreach nature of anions. Indeed, the formation of halogen bonds between anion guests and synthetic receptors have been demonstrated both in solution and in the solid state. ${ }^{20,22 \text {, }}$ 23

Aromatic interactions, such as $\pi-\pi$ stacking, $\mathrm{CH}-\pi$, cation- $\pi$, lone-pair- $\pi$ are also important on the stabilization of molecular architectures, particularly in biology. ${ }^{24}$ In the early $2000 s^{\prime}$ the possibility to establish anion- $\pi$ interactions has been demonstrated for the first time by Frontera, Deya and co-workers who described the interactions with anions and hexafluorobenzene in the solid state. ${ }^{25}$ It is indeed well known that the introduction of fluorine atoms in the benzene ring (i.e. moving from $\mathrm{C}_{6} \mathrm{H}_{6}$ to $\mathrm{C}_{6} \mathrm{~F}_{6}$ ) causes an inversion in the value of quadrupole moment $Q$ (from $Q_{\mathrm{CGH} 6}={ }^{\wedge}-29.0 \times 10^{-40}$ to $Q_{\mathrm{CGFG}}=$ 
$\left.31.7 \times 10^{-40} \mathrm{C} \mathrm{m}^{-2}\right),{ }^{26}$ thus favouring weak interactions involving the aromatic system.

Following our interest in the development of neutral anion receptors, we decided to investigate both in solution and in the solid state the role of the halogen substituents on the anion binding properties of a series of halogenated isophthalamides and dipicolineamides (L1-L6, Figure 1). In particular, we wanted to evaluate the ability of these receptors to establish different and combined weak interactions with anion guests depending on the substituents on the aromatic rings. Theoretical calculations helped us to get a deeper understanding of the interactions involved in the proposed systems.

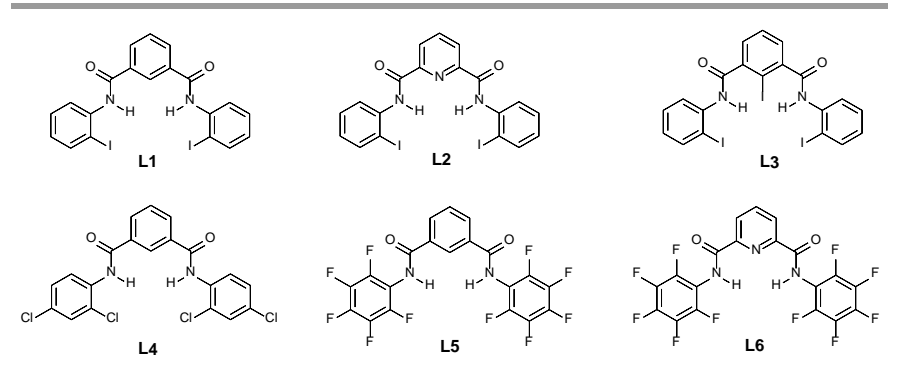

Figure 1 Receptors studied in the paper.

\section{Results and discussion}

The synthesis of receptors L1-L2 and L4 was carried out in $\mathrm{MeCN}$ by reacting commercially available isophtaloylchloride or pyridine-2,6-dicarbonyldichloride with the suitable halogenated aniline in the presence of $\mathrm{KOH}$. In the case of $\mathbf{L 3}$ the acyl chloride was synthesised by reacting the 2iodoisophtalic acid with thionyl chloride. The synthesis of receptor $\mathbf{L 5}$ has already been reported elsewhere. ${ }^{27}$ L6 was obtained by the reaction of pyridine-2,6-dicarbonyldichloride with pentafluoroaniline in DCM. All receptors were obtained in high yields (from $57 \%$ to $97 \%$ ). Synthetic details are reported in the Electronic Supplementary Information (ESI + , Figure S1). The anion binding properties of L1-L6 were evaluated in solution by means of ${ }^{1} \mathrm{H}-\mathrm{NMR}$ titrations (see ESI, Figures. S2$\mathrm{S} 8$ ) in DMSO- $d_{6}$ towards a set of anion guests $\left(\mathrm{F}^{-}, \mathrm{CN}^{-}, \mathrm{BzO}^{-}\right.$, $\mathrm{H}_{2} \mathrm{PO}_{4}^{-}$, and $\mathrm{Cl}^{-}$) as their tetrabutylammonium (TBA) salts. Stability constants for the formation of the 1:1 adducts (Table 1) were calculated using WinEQNMR (see ESI + , Figures S9S15). ${ }^{28}$
Table 1 Stability constants $\left(K a, \mathrm{M}^{-1}\right)$ for the 1:1 adducts of L1-L6 with the anions in considered in DMSO- $d_{6}$. In the case of $\mathbf{L} \mathbf{5}$ stability constants were determined following the downfield shift of the signal of the central phynal $\mathrm{CH} \mathrm{s}$ in orto positions to both amide groups. In the case of L1-L4, and $\mathbf{L 6}$ stability constants were determined following the downfield shift of the $\mathrm{NH}$ signal. All errors are estimated $<20 \%$ except for L6 with $\mathrm{Cl}^{-}$(error $<25 \%$ ).

\begin{tabular}{|c|c|c|c|c|c|}
\hline \multirow[t]{2}{*}{ Receptors } & \multicolumn{5}{|c|}{ Anions } \\
\hline & $\mathbf{F}^{-}$ & $\mathrm{CN}^{-}$ & $\mathrm{BzO}^{-}$ & $\mathrm{H}_{2} \mathrm{PO}_{4}^{-}$ & $\mathrm{Cl}^{-}$ \\
\hline L1 & n.i. ${ }^{a}$ & d. ${ }^{b}$ & n.i. ${ }^{a}$ & n.i. ${ }^{a}$ & n.i. ${ }^{a}$ \\
\hline L2 & $\mathrm{d}^{\mathrm{b}}$ & $\mathrm{d}^{\mathrm{b}}$ & n.i. $^{a}$ & n.i. ${ }^{a}$ & n.i. $^{a}$ \\
\hline L3 & n.i. $^{a}$ & $\mathrm{~d}^{\mathrm{b}}$ & n.i. $^{a}$ & n.i. ${ }^{a}$ & n.i. ${ }^{a}$ \\
\hline L4 & d. ${ }^{b}$ & d. ${ }^{b}$ & 224 & n.d. ${ }^{c}$ & n.i. ${ }^{a}$ \\
\hline L5 & d. ${ }^{b}$ & d. ${ }^{b}$ & 537 & 638 & 22 \\
\hline L6 & d. ${ }^{b}$ & $\mathrm{~d}^{\mathrm{b}}$ & 258 & n.d. ${ }^{c}$ & 47 \\
\hline
\end{tabular}

${ }^{a}$ None of the signals shifted upon addition of the tested anions; ${ }^{b}$ the amide $\mathrm{NH}$ signal disappeared upon addition of the tested anions; ${ }^{\mathrm{c}}$ the experimental data could not be fitted to a 1:1 or a 2:1 anion:receptor model. (n.i. = no interaction; $d$. = deprotonation; n.d. = not determined)

The results reported in Table 1 show that basic anions such as fluoride and cyanide caused, in most of the cases, the disappearance of the signal attributed to the amide $\mathrm{NHs}$ suggesting a deprotonation of the receptors. Indeed, in the attempt to crystallize the 1:1 adduct of $\mathbf{L} 6$ with TBAF in DMSO we instead obtained the crystal structure of the hydrated bisdeprotonated form of the receptor with two TBA units as the countercations $\left[\mathbf{L 6}^{2-}(\mathrm{TBA})_{2}\right] \cdot \mathrm{H}_{2} \mathrm{O}$ (see below). L1, L2, and L3 were not able to interact with any of the other anions considered, probably because of the steric hindrance of the iodine atoms which did not allow the formation of $\mathrm{H}$-bonds between the amide $\mathrm{NHs}$ and the anion guests (see discussion on crystal structures). The most interesting results were obtained for $\mathbf{L 5}$ and $\mathbf{L 6}$. In the case of $\mathbf{L 6}$ the classic downfield shift of the signal attributed to the amide $\mathrm{NHs}$ was observed upon addition of $\mathrm{BzO}^{-}, \mathrm{H}_{2} \mathrm{PO}_{4}^{-}$, and, to a less extent, $\mathrm{Cl}^{-}$(see ESI + Figures S2-S4). In the case of $\mathbf{L 5}$ a more peculiar behaviour was observed when the receptor was titrated with $\mathrm{TBAH}_{2} \mathrm{PO}_{4}$ (see ESI, Figure S5) and TBABzO (Figure 2). Upon addition of increasing amounts of $\mathrm{BzO}^{-}$a progressive decrease in the intensity of the signal at $10.82 \mathrm{ppm}$ (green star in Figure 2) attributed to the isophthalamide $\mathrm{NHs}$ and the concomitant formation of a new signal at $5.84 \mathrm{ppm}$ (red star in Figure 2) was observed. Moreover, the singlet signal at $8.63 \mathrm{ppm}$ (blue star in Figure 2), attributed to the phenyl $\mathrm{CH}$ pointing towards the pseudo-cavity of the receptor formed by the amide groups in syn-syn conformation, dramatically shifted downfield during the titration. 


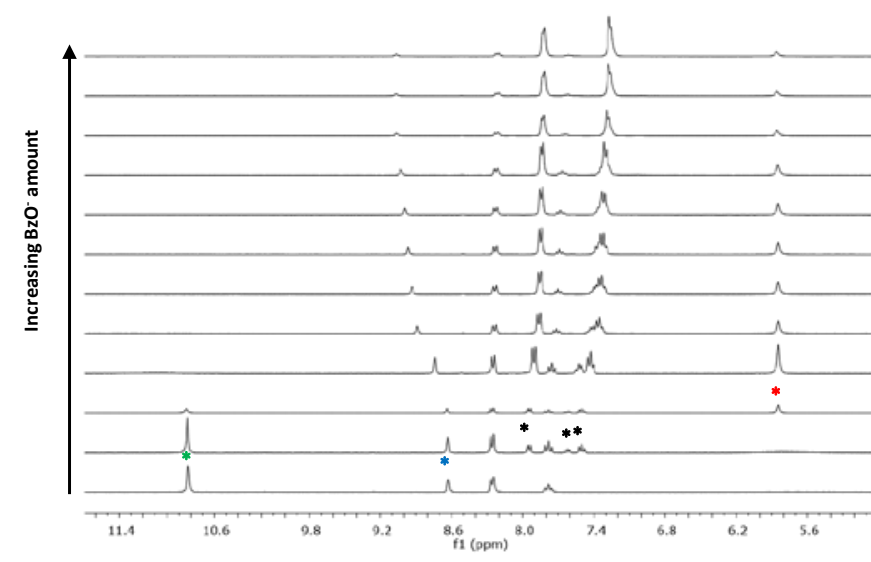

Figure 2 Stack plot of the ${ }^{1} \mathrm{H}-\mathrm{NMR}$ spectra of $\mathbf{L 5}$ upon addition of increasing amount of TBABzO in DMSO- $d_{6}$. Green star (isophtalamide $\mathrm{NH}$ ), blue sta (phenyl $\mathrm{CH}$ in orto position to the amide functions), black stars (BzO- signals), red star (new signal attributed to the non-coordinating isophtalamide $\mathrm{NH}$, see discussion)

Interestingly, also the chemical shifts of the proton signals of $\mathrm{BzO}^{-}$(black stars in Figure 2) were affected by the interaction with the host and shifted upfield. These observations suggest that upon addition of $\mathrm{BzO}^{-}$the two isophthalamide $\mathrm{NH}$ protons lose their chemical equivalency with the one (at 10.82 ppm) interacting with the anion that experiments a slow exchange and disappears, and the other (at $5.84 \mathrm{ppm}$ ) that is not affected by the guest presence. ${ }^{29}$ We could then hypothesise the formation of a mono-cooordinated adduct assisted by the formation of a $\mathrm{CH}---\mathrm{OBz}$ hydrogen bond, i.e. receptor $\mathbf{L} 5$ likely coordinates $\mathrm{BzO}^{-}$in a syn-anti conformation (see Scheme1).

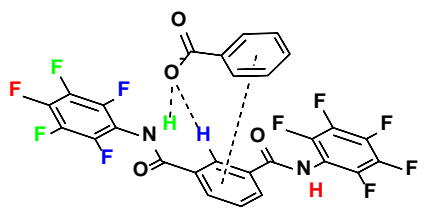

Scheme 1 Proposed binding mode for the formation of the 1:1 adduct between $\mathbf{L} \mathbf{5}$ and $\mathrm{BzO}$.

The fact that receptor $\mathbf{L} \mathbf{5}$ might adopt this conformation in solution even in the absence of anions was previously suggested by Hunter and co-workers. ${ }^{27}$ The chemical shift of the $\mathrm{BzO}^{-}$signals might also suggest the formation of $\pi-\pi$ stacking interactions between the benzoate ring and the isophthalamide ring (Scheme 1).

A similar behaviour was also observed when titrating $\mathbf{L} \mathbf{5}$ with $\mathrm{TBAH}_{2} \mathrm{PO}_{4}$ (see ESI + Figure S5). In the case of chloride, as the interaction is weaker compared to the other anions considered, we were not able to observe the formation of the mono-coordinated adduct as the preponderant species (see ESI + , Figure S6).

In order to get a deeper insight into the nature of the adducts between receptor $\mathbf{L} \mathbf{5}$ and anions we also performed ${ }^{19} \mathrm{~F}-\mathrm{NMR}$ titrations (see ESI + Figure S7 and S8 for the titrations with $\mathrm{H}_{2} \mathrm{PO}_{4}{ }^{-}$and $\mathrm{Cl}^{-}$, respectively) in DMSO- $d_{6}$. As shown in Figure 3, the free receptor presents six distinct signals in the ${ }^{19} \mathrm{~F}-\mathrm{NMR}$ spectrum, demonstrating that in solution the two pentafluorophenyl rings are not chemically equivalent. Upon addition of increasing amounts of benzoate only three signals were affected by the presence of the anion guest and, in particular, the triplet at $-157.41 \mathrm{ppm}$ (attributed to the $\mathrm{F}$ atom in para position with respect to the isophtalamide $\mathrm{NH}$, red star in Figure 3) shifted upfield and broadened. The triplet at 162.42 (attributed to the $\mathrm{F}$ atom in meta position with respect to the isophtalamide $\mathrm{NH}$, green star in Scheme 1) and the doublet centred at -145.58 (attributed to the $\mathrm{F}$ atom in orto position with respect to the isophtalamide $\mathrm{NH}$, blue star in Scheme 1) also upfield shifted and broaden to a less extent. These results corroborate the hypothesis reported above on the basis of the ${ }^{1} \mathrm{H}-\mathrm{NMR}$ titration, i.e. the non-equivalence of the two half of the receptor bound to the benzoate and the possibility to have multiple host-guest interactions (Scheme 1)

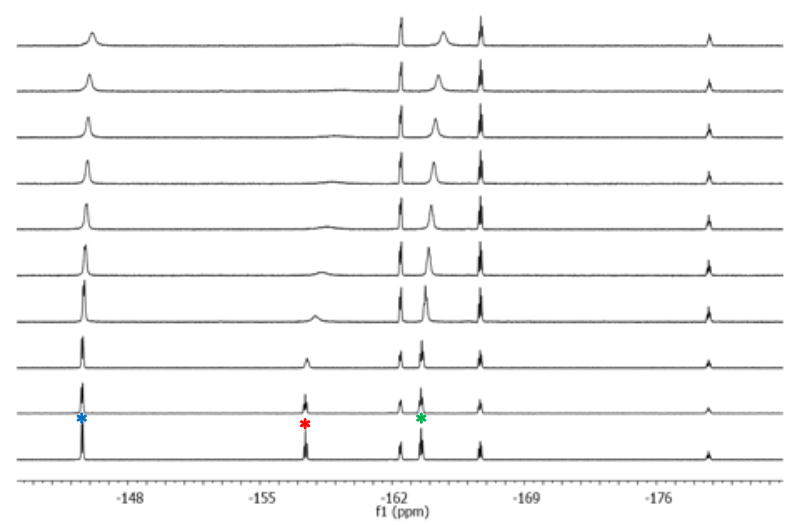

Figure 3 Stack plot of the ${ }^{19} \mathrm{~F}-\mathrm{NMR}$ spectra of $\mathbf{L} \mathbf{5}$ upon addition of increasing amount of TBABzO in DMSO- $d_{6}$. Red star ( $\mathrm{F}$ atom in para position), blue star ( $\mathrm{F}$ atom in orto position), green star ( $\mathrm{F}$ atom in meta position).

Theoretical calculations were carried out to understand the nature of the adducts formed in solution. $20 \mathrm{~ns}$ long metadynamics was used to explore the structural (conformational) dynamics of the two interacting systems ( $\mathbf{L} 5$ with $\mathrm{BzO}^{-}$and $\mathrm{H}_{2} \mathrm{PO}_{4}^{-}$anions and $\mathbf{L}^{-}$with $\mathrm{BzO}^{-}$) and to enhance the sampling of the conformational space of receptor/anion adducts. A principal component analysis (PCA) was carried out on the frames from the metadynamic trajectories to highlight the prevalent conformations occurring between the interacting structures (receptor/anion systems). To this aim, the frames from the metadynamic trajectories were characterized by the $\mathrm{H}$-bond distances and angles computed on the two interacting systems (See ESI + , Table S1). In addition, the centroid-centroid distances separating the aromatic groups of $\mathbf{L 5}$ or $\mathbf{L 6}$ and benzoate anion were measured in order to evidence the possible presence of $\pi$ stacking interactions.

Plotting the MetaD frames (about 400 for each adduct trajectory) into the space defined by the principal components PCs allows the snapshots to be grouped into distinct conformational classes based on conformers' conformational similarity. In all the studied systems the isophthalamide hydrogens play a vital role in forming $\mathrm{H}$-bond interactions with the considered in the calculations substrate. Ligands can use both the isophthalamide $\mathrm{NH}$ hydrogens to bind the anion 
substrate, or only one of them, giving conformations which in the following will be defined as symmetric or non-symmetric, respectively. Notably, the non-symmetric conformation (only one isophthalamide hydrogen used in $\mathrm{H}$-bond formation) are dominant for both adducts formed by $\mathbf{L} \mathbf{5}$, while the symmetric ones are the most important in the L6/benzoate system, confirming the results observed experimentally (see ESI + for

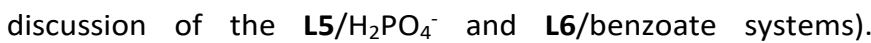
Performing a PC analysis and plotting the trajectory snapshots into the PC1 vs PC2 space $(71 \%$ of the overall variance explained) revealed three distinct clusters for the system L5/benzoate (Figure 4). Cluster 1 (grey points) refers to conformers where no interactions occur between $\mathbf{L 5}$ and benzoate; cluster 2 (magenta and light pink points) refers to conformers where one $\mathrm{H}$-bond is formed between the receptor $\mathbf{L} \mathbf{5}$ and the anion and cluster $\mathbf{3}$ (red and brown points) describes the situation where two $\mathrm{H}$-bonds are formed.

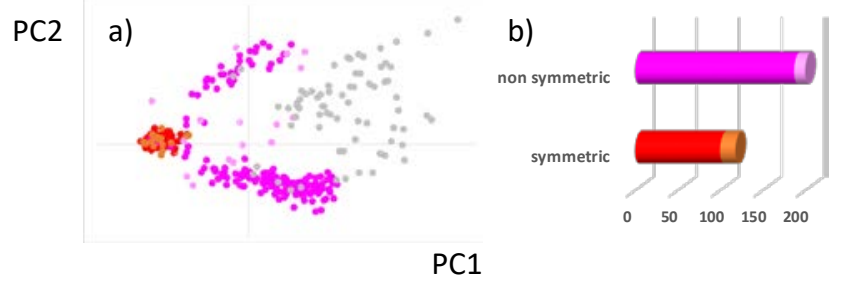

Figure 4 L5/Benzoate adduct: results from PCA analysis of frames from metadynamic trajectory for the L5/BzO- system: (a) PC1 vs PC2 score plot; (b) counting of the symmetric and non-symmetric frames classified on the basis of the ligand/substrate $\mathrm{H}$ bonds. (magenta: $1 \mathrm{H}$-bond; light pink: $1 \mathrm{H}$-bond and $\pi$-stacking interaction; red: $2 \mathrm{H}$ bond; brown: $2 \mathrm{H}$-bond and $\pi$-stacking interaction; grey: no interaction)

In some symmetric (brown points) and non-symmetric (light pink points) conformers, a $\pi-\pi$ interaction reinforces the $H$ bond ones, contributing to stabilize the adduct. Representative structures for these clusters are shown in Figure 5. Furthermore, in some non-symmetric (light pink points) conformers (see Figure $5 \mathrm{~b}$ ) a weak $\mathrm{C}-\mathrm{H} \cdots \mathrm{O} \mathrm{H}$-bond involving the phenyl $\mathrm{CH}$ in orto position to the two amide functions is also observed in agreement with the ${ }^{1} \mathrm{H}-\mathrm{NMR}$ measurements. Interestingly, no-halogen bonds are observed.
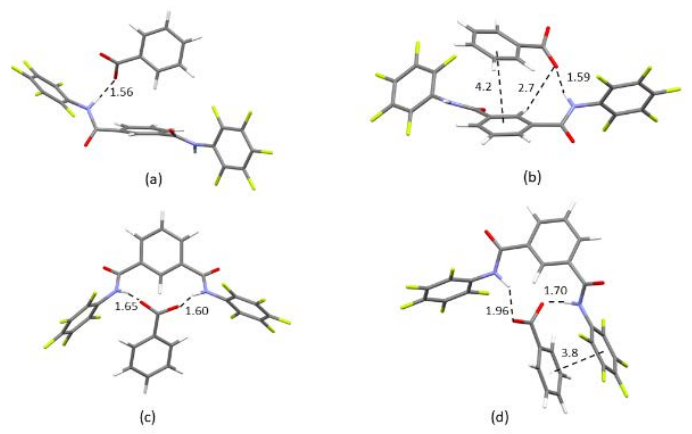

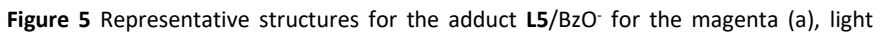
pink (b), red (c) and brown (d) clusters.
In order to study the anion binding properties of the receptors in solid state we crystallised L1-L6 by slow evaporation from solutions of the receptors, in the absence and in the presence of TBA salts of the suitable anion specie and as free receptors. Details of crystallization experiments are reported in ESI †. In general, whatever the conditions used, we obtained good quality crystals only for receptors L1, L2, L4, L5 and L6. Crystallizations of L3 (even in the presence of anionic species), only resulted in precipitation of fine powders.

The results of the crystal structure determination (see ESI + ) show that most of the receptors crystallised as their neutral form, even in the presence of an excess of different anion species. In the case of L1-L4, this is consistent with the results from solution studies that suggested no particular affinities between receptors L1-L4 and the set of anions chosen for this study. In the case of $\mathbf{L 5}$ and $\mathbf{L 6}$, although the results from solution suggest a good affinity toward $\mathrm{BzO}^{-}$and $\mathrm{H}_{2} \mathrm{PO}_{4}^{-}$, the only structures we could isolate corresponded to the simple receptor unit for L5, crystallised in the absence of anions, and the hydrated TBA salt of the deprotonated receptor $\mathbf{L} \mathbf{6}\left[\mathbf{L 6}^{2-}\right.$ $\left.(\mathrm{TBA})_{2}\right] \cdot \mathrm{H}_{2} \mathrm{O}$. The analysis of the molecular conformation in the solid state shows that in most of the structures the receptor molecule adopts an anti-anti conformation, with the $\mathrm{NH}$ donors pointing in the same direction with respect to the aromatic spacer. This is observed in the case of $\mathbf{L 1}, \mathbf{L} \mathbf{4}$ and $\mathbf{L 5}$ (Figure 6a-c). For L1 and L4 the two halo-substituted phenyl rings lie coplanar to the central aromatic spacer (Figure 6a-b, on the left), while, in the case of $\mathbf{L 5}$, these are oriented perpendicular to the plane of the aromatic spacer (Figure 6c, on the left). Interestingly, this conformation is consistent with the conformer proposed for the dominant non-symmetric binding mode of the $\mathrm{L5}^{2} \mathrm{H}_{2} \mathrm{PO}_{4}^{-}$adduct (see ESI + , figure S17 a). The common molecular conformation observed in L1, L4 and L5 is reflected in common structural features. In all the structures, adjacent receptor molecules interact with each other via $\mathrm{N}-\mathrm{H} \cdots \mathrm{O}$ hydrogen bond ( $\mathrm{N} \cdots \mathrm{O}$ distances are in the range 2.814(1)-2.884(3) $\AA$ ) to form infinite stacks (Figure 6a-c, on the right). These are then differently packed along the remaining two directions of the crystallographic cell, generating different arrangements in the crystal lattice (for a detailed crystal packing description see ESI †). 


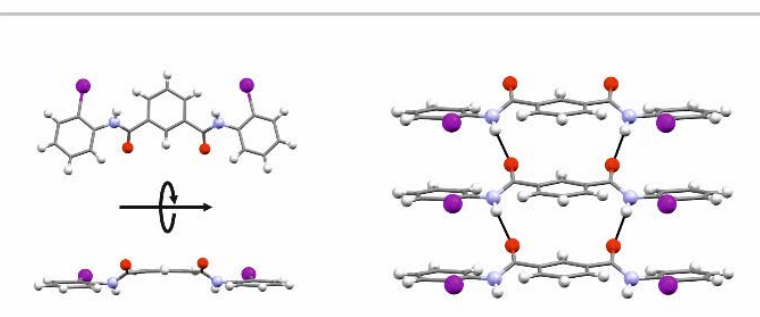

(a)
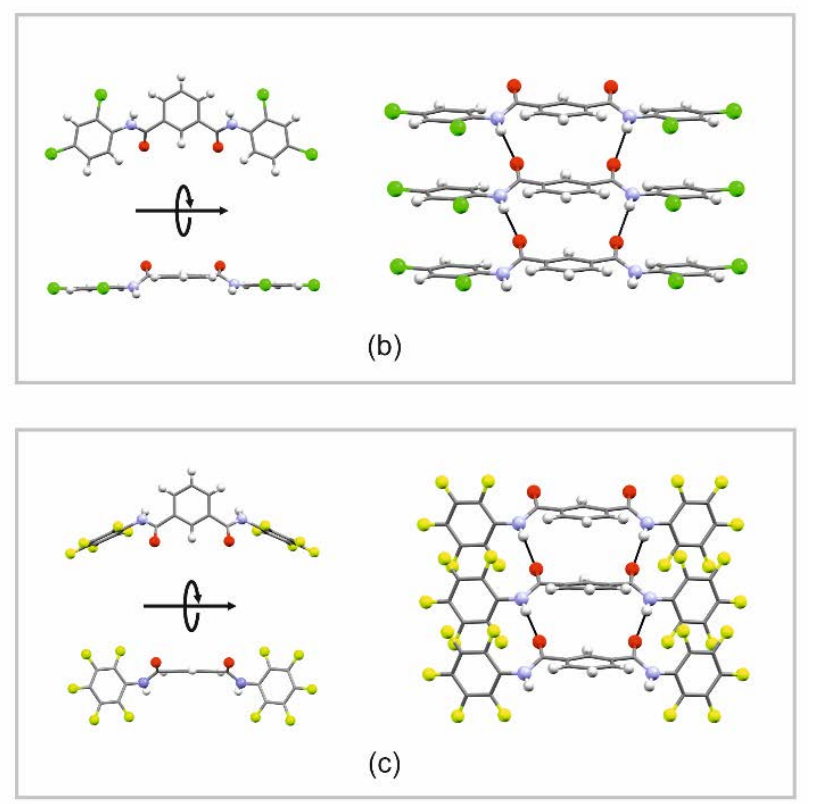

Figure 6. Molecular conformations and main intermolecular interactions observed in crystal structures of the receptors (a) L1, (b) L4 and (c) L5. Receptors units stack along the $b$-direction ( $\mathbf{L} \mathbf{1}$ and $\mathbf{L} \mathbf{4}$ ) and along the $a c$-direction (L5)

In structures $\mathbf{L} 2$ and $\left[\mathbf{L 6}^{2-}(\mathrm{TBA})_{2}\right] \cdot \mathrm{H}_{2} \mathrm{O}$, the receptor molecule adopts a syn-syn conformation with the amide $\mathrm{NHs}$ (or the deprotonated $\mathrm{N}^{-}$in the case of $\left[\mathrm{LG}^{2-}(\mathrm{TBA})_{2}\right] \cdot \mathrm{H}_{2} \mathrm{O}$ oriented towards the centre of the pseudo-cavity.

In the case of $\mathbf{L 2}$, the pseudo-cavity is locked, due the steric hindrance generated by the iodo-substituted groups. One of the iodophenyl rings lies coplanar to the pyridine spacer forming an intramolecular $\mathrm{C}-\mathrm{H} \cdots \mathrm{O}$ hydrogen bond, involving the amido carbonyl oxygen and the aromatic $\mathrm{CH}$ in orto position of the iodo-phenyl moiety ( $\mathrm{H} \cdots \mathrm{O}$ distance is $2.274(2)$ $\AA$ ). The other iodo-phenyl ring is tilted, pointing the iodo substituted group above the plane of the pyridine spacer (Fig 7 a). This particular orientation of the iodo-phenyl ring promotes the formation of stacks of molecules that propagate along the $a$-direction connected via unusually short $|\cdots|$ interactions $(|\cdots|$ distance 3.599(1) $\AA$, see Figure 7a on the right). This molecular arrangement is then packed along the remaining two directions of the crystallographic cell generating a crystal packing represented in the ESIt (Figure S23).

Conversely, in the case of the anion $\mathbf{L} \mathbf{6}^{2-}$ in $\left[\mathbf{L G}^{2-}(\mathrm{TBA})_{2}\right] \cdot \mathrm{H}_{2} \mathrm{O}$, the pseudo-cavity is completely accessible and, indeed, it is occupied by a water molecule connected to the deprotonated amido $\mathrm{N}^{-} \mathrm{H}$-bond acceptors via $\mathrm{O}-\mathrm{H}^{-\cdots} \mathrm{N}^{-}$hydrogen bonds $\left(\mathrm{H} \ldots \mathrm{N}^{-}\right.$ distances are in the range 1.98-2.14 $\AA$ ).

Like the case of $\mathbf{L 5}$, also in the case of $\left[\mathbf{L 6}^{2-}(\mathrm{TBA})_{2}\right] \cdot \mathrm{H}_{2} \mathrm{O}$ the fluoro-substituted phenyl rings are both tilted orthogonally with respect the plane of the pyridine spacer. This specific conformation is consistent with those proposed for the symmetric binding mode in the $\mathrm{L}^{-} / \mathrm{BzO}^{-}$adduct (see ESI+, Figure S19 c-e). Crystal packing is reported in ESIt, Figure S24. As described in ESI, the anionic $\mathbf{L 6}^{2-} \cdot \mathrm{H}_{2} \mathrm{O}$ adduct unit is then surrounded by $\mathrm{TBA}^{+}$cations (Fig. $7 \mathrm{~b}$, right) interacting via a series of weak $\mathrm{C}-\mathrm{H} \cdots \mathrm{O}, \mathrm{C}-\mathrm{H} \cdots \mathrm{N}$ and $\mathrm{C}-\mathrm{H} \cdots \mathrm{F}$ contacts $(\mathrm{H} \cdots \mathrm{O}$ in the range $2.33-2.70 \AA, \mathrm{H} \cdots \mathrm{F}$ in the range $2.33-2.64 \AA$ and $\mathrm{H} \cdots \mathrm{N}$ in the range $2.51-2.73 \AA$ ).
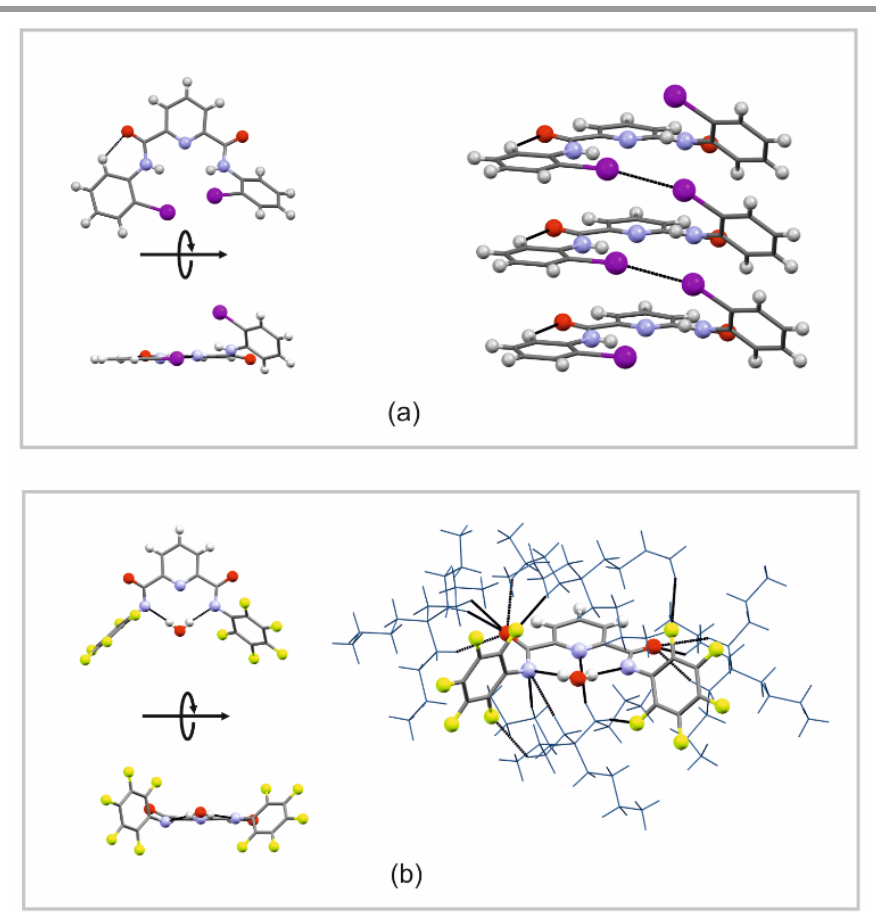

Figure 7. Molecular conformations and main intermolecular interactions observed in crystal structures (a) $\mathbf{L} 2$ and (b) $\mathbf{L} \mathbf{6}^{2-}(\mathrm{TBA})_{2} \cdot \mathrm{H}_{2} \mathrm{O}$._Stacks of interacting molecules of $\mathbf{L} \mathbf{2}$ develop along the $a$-direction.

\section{Experimental}

\section{General procedures}

All reactions were performed in oven-dried glassware under a slight positive pressure of nitrogen. ${ }^{1} \mathrm{H}-\mathrm{NMR}(300 \mathrm{MHz}),{ }^{13} \mathrm{C}$ NMR (75 MHz) and ${ }^{19} \mathrm{~F}-\mathrm{NMR}(282 \mathrm{MHz})$ spectra were determined on a Bruker Avance $300 \mathrm{MHz}$. Chemical shifts for ${ }^{1} \mathrm{H}-\mathrm{NMR}$ are reported in parts per million ( $\left.\mathrm{ppm}\right)$, calibrated to the residual solvent peak set, with coupling constants reported in Hertz $(\mathrm{Hz})$. The following abbreviations are used for spin multiplicity: $\mathrm{s}=$ singlet, $\mathrm{d}=$ doublet, $\mathrm{t}=$ triplet, $\mathrm{m}=$ multiplet . Chemical shifts for ${ }^{13} \mathrm{C}-\mathrm{NMR}$ are reported in $\mathrm{ppm}$, relative to the central line of a septet at $\delta=39.52 \mathrm{ppm}$ for deuteriodimethylsulfoxide. Chemical shifts for ${ }^{19} \mathrm{~F}-\mathrm{NMR}$ are reported in $\mathrm{ppm}$, relative to trichlorofluoromethane $\left(\mathrm{CFCl}_{3}\right)$. 
Infrared (IR) spectra were recorded on a NICOLET 5700 FT-IR spectrophotometer and reported in wavenumbers $\left(\mathrm{cm}^{-1}\right)$. Elemental analyses were obtained using a PerkinEImer Series II - 2400. All solvents and starting materials were purchased from commercial sources where available. Proton NMR titrations were performed by adding aliquots of the putative anionic guest (as the TBA salt, $0.075 \mathrm{M}$ ) in a solution of the receptor $(0.005 \mathrm{M})$ in $D M S O-d_{6}$ to a solution of the receptor (0.005M).

Metadynamics simulations were performed for the $\mathbf{L}$ /benzoate, $\mathbf{L} 5 / \mathrm{H}_{2} \mathrm{PO}_{4}{ }^{-}$and $\mathbf{L 6}$ /benzoate adducts. Each binary system was solvated in an orthorhombic box of DMSO molecules, extended $50 \AA$ away from any ligands atom. PCA analyses were performed to study results from each metadynamics trajectory. Experimental details for theoretical calculations and analyses are reported in ESIt.

The SCXRD data was acquired and processed using software and instruments from Rigaku. Data was solved with either

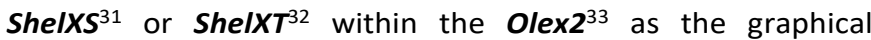
interface. These solutions were then refined with ShelXL $2018 / 3^{34}$ using full matrix least squares minimisation on $\boldsymbol{F}^{2}$. Full details of the instrumentation and software used for each structure together with crystallographic details (Table S2) can be found in the ESIt.

\section{Synthesis}

\section{Synthesis of N,N'-bis(2-iodophenyl)isophthalamide (L1)}

To a solution of 2-iodoaniline $(0.108 \mathrm{~g}, 0.50 \mathrm{mmol})$ in $7 \mathrm{~mL}$ of $\mathrm{MeCN}, 247 \mu \mathrm{L}$ di $\mathrm{KOH} 2 \mathrm{M}$ were added. Then a solution of isophthaloyl chloride $(0.050 \mathrm{~g}, 0.245 \mathrm{mmol})$ in $5 \mathrm{~mL}$ of $\mathrm{MeCN}$ was added dropwise to the reaction mixture. The solution was stirred at room temperature for $2 \mathrm{~h}$. After that time the desired product was obtained as a white precipitate which was filtered off and washed with DCM. Yield $=72 \%(0.073 \mathrm{~g}, 0.12$ mmol), M.p. $=220^{\circ} \mathrm{C}$ with decomposition. ${ }^{1} \mathrm{H}-\mathrm{NMR}(400 \mathrm{MHz}$, DMSO- $\left.d_{6}, 298 \mathrm{~K}\right), \delta_{\mathrm{H}}: 10.25(\mathrm{~s}, \mathrm{NH}, 2 \mathrm{H}), 8.64(\mathrm{~s}, 1 \mathrm{H}), 8.23(\mathrm{~d}, \mathrm{~J}=$ $4 \mathrm{~Hz}, 2 \mathrm{H}), 7.95(\mathrm{~d}, \mathrm{~J}=8 \mathrm{~Hz}, 1 \mathrm{H}), 7.73(\mathrm{t}, \mathrm{J}=8 \mathrm{~Hz}, 1 \mathrm{H}), 7.51-7.43$ $(\mathrm{m}, 4 \mathrm{H}), 7.08(\mathrm{t}, \mathrm{J}=8 \mathrm{~Hz}, 2 \mathrm{H}) .{ }^{13} \mathrm{C}-\mathrm{NMR}\left(100 \mathrm{MHz}\right.$, DMSO- $d_{6}$, $298 \mathrm{~K}), \delta_{\mathrm{c}}: 164.80,139.74,138.91,134.60,130.66,128.85$, $128.76,128.59,128.42,127.30,98.33 . \mathrm{IR}\left(\mathrm{KBr}\right.$ disk), $v_{\mathrm{NH}}=3257$ $\mathrm{cm}^{-1}, v_{\mathrm{CO}}=1656 \mathrm{~cm}^{-1}$. Elemental Analysis experimental (calculated \%): C 42.35 (42.28), H 2.42 (2.48), N 4.90 (4.93).

\section{N,N'-bis(2-iodophenyl)pyridine-2,6-dicarboxamide (L2)}

To a solution of 2-iodoaniline $(0.103 \mathrm{~g}, 0.47 \mathrm{mmol})$ in $10 \mathrm{~mL}$ of MeCN, $250 \mu \mathrm{L}$ di $\mathrm{KOH} 2 \mathrm{M}$ were added. Then a solution of 2,6pyridine-dicarbonyl dichloride $(0.050 \mathrm{~g}, 0.245 \mathrm{mmol})$ in $3 \mathrm{~mL}$ of $\mathrm{MeCN}$ was added dropwise to the reaction mixture. The solution was stirred at room temperature overnight. After that time the desired product was obtained as a white precipitate which was filtered off and washed with $\mathrm{MeCN}$. Yield $=72 \%$ $(0.101 \mathrm{~g}, 0.18 \mathrm{mmol}), \mathrm{M} . \mathrm{p} .=182^{\circ} \mathrm{C} .{ }^{1} \mathrm{H}-\mathrm{NMR}(400 \mathrm{MHz}$, DMSO$\left.d_{6}, 298 \mathrm{~K}\right), \delta_{\mathrm{H}}: 10.94(\mathrm{~s}, \mathrm{NH}, 2 \mathrm{H}), 8.39(\mathrm{~d}, \mathrm{~J}=8 \mathrm{~Hz}, 2 \mathrm{H}), 8.32(\mathrm{t}, \mathrm{J}$ $=8 \mathrm{~Hz}, 1 \mathrm{H}), 7.98(\mathrm{~d}, \mathrm{~J}=8 \mathrm{~Hz}, 2 \mathrm{H}), 7.56(\mathrm{~d}, \mathrm{~J}=8 \mathrm{~Hz}, 2 \mathrm{H}), 7.49(\mathrm{t}$, $\mathrm{J}=8 \mathrm{~Hz}, 2 \mathrm{H}), 7.11(\mathrm{t}, \mathrm{J}=8 \mathrm{~Hz}, 2 \mathrm{H}) .{ }^{13} \mathrm{C}-\mathrm{NMR}(100 \mathrm{MHz}$, DMSO$\left.d_{6}, 298 \mathrm{~K}\right), \delta_{\mathrm{C}}: 161.80,148.44,140.20,139.31,138.94,128.90$, $128.62,128.43,125.23,127.30,98.80 . \mathrm{IR}\left(\mathrm{KBr}\right.$ disk), $v_{\mathrm{NH}}=3317$ $\mathrm{cm}^{-1}, v_{\mathrm{cO}}=1692 \mathrm{~cm}^{-1}$. Elemental Analysis experimental (calculated \%): C 40.06 (40.10), H 2.36 (2.30), N 7.41 (7.38).

\section{2-iodobenzene-1,3-dicarbonyl dichloride (1)}

In a round bottom flask 2-iodo-1,3-benzenedicarboxylic acid $(0.155 \mathrm{~g}, 0.53 \mathrm{mmol})$ and $2 \mathrm{~mL}$ of thionyl chloride were stirred under nitrogen atmosphere for $2 \mathrm{~h} 30 \mathrm{~min}$ at $80^{\circ} \mathrm{C}$. The solvent was then evaporated to give a yellow crystalline solid which used without further purification. Yield $=90 \%(0.154 \mathrm{~g}, 0.470$ $\mathrm{mmol})$.

\section{2-iodo-N,N'-bis(2-iodophenyl)isophthalamide (L3)}

To a solution of 2-iodoaniline $(0.235 \mathrm{~g}, 1.071 \mathrm{mmol})$ in $10 \mathrm{~mL}$ of dry MeCN, $535 \mu \mathrm{L}$ di $\mathrm{KOH} 2 \mathrm{M}$ were added. Then a solution of $1(0.154 \mathrm{~g}, 0.470 \mathrm{mmol})$ in $10 \mathrm{~mL}$ of $\mathrm{MeCN}$ was added dropwise to the reaction mixture. The solution was stirred at room temperature overnight. After that time the desired product was obtained as a brown precipitate which was filtered off and washed with $\mathrm{MeCN}$ to yield a white solid. Yield $=57 \%(0.185 \mathrm{~g}, 0.266 \mathrm{mmol}), \mathrm{M} . \mathrm{p} .=250^{\circ} \mathrm{C} .{ }^{1} \mathrm{H}-\mathrm{NMR}(100$ $\left.\mathrm{MHz}, \mathrm{DMSO}-d_{6}, 298 \mathrm{~K}\right), \delta_{\mathrm{H}}: 10.15(\mathrm{~s}, \mathrm{NH}, 2 \mathrm{H}), 7.94(\mathrm{~d}, \mathrm{~J}=8 \mathrm{~Hz}$, $2 \mathrm{H}), 7.66-7.44(\mathrm{~m}, 7 \mathrm{H}), 7.09(\mathrm{t}, \mathrm{J}=8 \mathrm{~Hz}, 2 \mathrm{H}) .{ }^{13} \mathrm{C}-\mathrm{NMR}(100$ $\left.\mathrm{MHz}, \mathrm{DMSO}-d_{6}, 298 \mathrm{~K}\right), \delta_{\mathrm{C}}: 167.72,144.06,139.16,139.03$, 129.42, 129.04, 128.79, 128.43, 128.03, 97.79, 92.32. IR (KBr disk), $v_{\mathrm{NH}}=3231 \mathrm{~cm}^{-1}, v_{\mathrm{CO}}=1663 \mathrm{~cm}^{-1}$. Elemental Analysis experimental (calculated \%): C 34.58 (34.51), H 1.93 (1.89), N 3.99 (4.04).

\section{N,N'-bis(2,4-dichlorophenyl)isophthalamide (L4)}

To a solution of 2,4-dichloroaniline $(0.150 \mathrm{~g}, 0.923 \mathrm{mmol})$ in 9 $\mathrm{mL}$ of $\mathrm{MeCN}, 450 \mu \mathrm{L}$ di $\mathrm{KOH} 2 \mathrm{M}$ were added. Then a solution of isophtaloyl dichloride $(0.090 \mathrm{~g}, 0.4453 \mathrm{mmol})$ in $9 \mathrm{~mL}$ of MeCN was added dropwise to the reaction mixture. The solution was stirred at room temperature overnight. After that time the desired product was obtained as a white precipitate which was filtered off. Yield $=97 \%(0.194 \mathrm{~g}, 0.426 \mathrm{mmol})$, M.p. $=230^{\circ} \mathrm{C}$ with decomposition. ${ }^{1} \mathrm{H}-\mathrm{NMR}\left(400 \mathrm{MHz}, \mathrm{DMSO}-d_{6}, 298\right.$ K), $\delta_{H}: 10.40(\mathrm{~s}, \mathrm{NH}, 2 \mathrm{H}), 8.62(\mathrm{~s}, 1 \mathrm{H}), 8.21(\mathrm{~d}, \mathrm{~J}=8 \mathrm{~Hz}, 2 \mathrm{H})$, 7.73-7.68 (m, 3H), $7.51(\mathrm{~d}, \mathrm{~J}=4 \mathrm{~Hz}, 2 \mathrm{H}), 7.49(\mathrm{~d}, \mathrm{~J}=4 \mathrm{~Hz}, 2 \mathrm{H})$. ${ }^{13} \mathrm{C}-\mathrm{NMR}\left(100 \mathrm{MHz}, \mathrm{DMSO}-d_{6}, 298 \mathrm{~K}\right), \delta_{\mathrm{C}}: 168.06,137.36$, 137.16, 134.07, 138.94, 133.82, 132.77, 132.21, 131.96, 130.78, 130.51. IR (KBr disk), $v_{\mathrm{NH}}=3279 \mathrm{~cm}^{-1}, v_{\mathrm{CO}}=1662 \mathrm{~cm}^{-1}$. Elemental Analysis experimental (calculated \%): C 52.87 (52.90), H 2.62 (2.66), N 6.21 (6.17).

\section{N,N'-bis(perfluorophenyl)isophthalamide (L5)}

To a solution of pentafluoroaniline $(1.806 \mathrm{~g}, 9.851 \mathrm{mmol})$ in 10 $\mathrm{mL}$ of DCM a solution of isophtaloyl dichloride $(0.600 \mathrm{~g}, 2.463$ $\mathrm{mmol}$ ) in $10 \mathrm{~mL}$ of DCM was added. The solution was stirred at room temperature for $72 \mathrm{~h}$. The formation of a white precipitate was observed. The reaction mixture was diluted with further $20 \mathrm{~mL}$ of DCM and washed with $\mathrm{NaOH} 1 \mathrm{M}$ (3x 10 $\mathrm{mL}$ ). The white precipitate was dissolved. Then the organic phase was washed with $\mathrm{HCl} 1 \mathrm{M}(3 \times 10 \mathrm{~mL})$ and dried over $\mathrm{Na}_{2} \mathrm{SO}_{4}$. The solvent was removed at reduced pressure to give the desired product as a white solid. Yield $=90 \%(1.094 \mathrm{~g}$, 
$2.198 \mathrm{mmol})$. M.p. $=263^{\circ} \mathrm{C} .{ }^{1} \mathrm{H}-\mathrm{NMR}\left(300 \mathrm{MHz}, \mathrm{DMSO}-d_{6}, 298\right.$ $\mathrm{K}), \delta_{\mathrm{H}}: 10.82(\mathrm{~s}, \mathrm{NH}, 2 \mathrm{H}), 8.63(\mathrm{~s}, 1 \mathrm{H}), 8.26(\mathrm{~d}, \mathrm{~J}=8 \mathrm{~Hz}, 2 \mathrm{H}), 7.78$ $(t, J=9 \mathrm{~Hz}, 1 \mathrm{H}) \cdot{ }^{13} \mathrm{C}-\mathrm{NMR}\left(125 \mathrm{MHz}, \mathrm{DMSO}-d_{6}, 298 \mathrm{~K}\right), \delta_{\mathrm{c}}$ : 167.98, 135.99, 134.86, 132.40, 130.86. ${ }^{19} \mathrm{~F}-\mathrm{NMR}(282 \mathrm{MHz}$, DMSO- $\left.d_{6}, 298 \mathrm{~K}\right), \delta_{\mathrm{F}}:-145.62(\mathrm{~d}, \mathrm{~J}=18.91 \mathrm{~Hz}),-157.41(\mathrm{t}, \mathrm{J}=$ $22.36 \mathrm{~Hz}$ ), $-162.42(\mathrm{q}, \mathrm{J}=9.40 \mathrm{~Hz}),-163.54(\mathrm{t}, \mathrm{J}=21.05 \mathrm{~Hz})$, $166.67(\mathrm{t}, \mathrm{J}=20.63 \mathrm{~Hz}),-178.75(\mathrm{~m}) . \mathrm{IR}\left(\mathrm{KBr}\right.$ disk), $v_{\mathrm{NH}}=3244$ $\mathrm{cm}^{-1}, v_{\mathrm{CO}}=1674 \mathrm{~cm}^{-1}$. Elemental Analysis experimental (calculated \%): C 48.39 (48.41), H 1.25 (1.22), N 5.59 (5.64).

\section{N,N'-bis(perfluorophenyl)pyridine-2,6-dicarboxamide (L6)}

To a solution of pentafluoroaniline $(1.800 \mathrm{~g}, 9.831 \mathrm{mmol})$ in 10 $\mathrm{mL}$ of DCM a solution of isophtaloyl dichloride $(0.502 \mathrm{~g}, 2.467$ $\mathrm{mmol}$ ) in $10 \mathrm{~mL}$ of DCM was added. The solution was stirred at room temperature for $24 \mathrm{~h}$. The formation of a pink precipitate was observed. The precipitate was filtered off and the filtrate was evaporated to yield a pink oil which was purified with flash chromatography using DCM as eluent. The desired product was obtained as a white microcrystalline solid. Yield $=75 \%$ (0.912 g, $1.834 \mathrm{mmol})$. M.p. $=253^{\circ} \mathrm{C} .{ }^{1} \mathrm{H}-\mathrm{NMR}(300$ $\left.\mathrm{MHz}, \mathrm{DMSO}-d_{6}, 298 \mathrm{~K}\right), \delta_{\mathrm{H}}: 11.09(\mathrm{~s}, \mathrm{NH}, 2 \mathrm{H}), 8.44(\mathrm{~d}, \mathrm{~J}=8.4$ $\mathrm{Hz}, 2 \mathrm{H}), 8.37(\mathrm{~d}, \mathrm{~J}=8.4 \mathrm{~Hz}, 1 \mathrm{H}) .{ }^{13} \mathrm{C}-\mathrm{NMR}\left(125 \mathrm{MHz}\right.$, DMSO- $d_{6}$, $298 \mathrm{~K}), \delta_{\mathrm{C}}: 165.09,150.36,143.74,130.12 .{ }^{19} \mathrm{~F}-\mathrm{NMR}(282 \mathrm{MHz}$, DMSO- $\left.d_{6}, 298 \mathrm{~K}\right), \delta_{\mathrm{F}}:-145.04(\mathrm{~d}, \mathrm{~J}=19.74 \mathrm{~Hz}),-156.17(\mathrm{t}, \mathrm{J}=$ $22.56 \mathrm{~Hz}),-163.01(\mathrm{t}, \mathrm{J}=22.56 \mathrm{~Hz}) . \mathrm{IR}\left(\mathrm{KBr}\right.$ disk), $v_{\mathrm{NH}}=3297 \mathrm{~cm}^{-}$ ${ }^{1}, v_{\mathrm{CO}}=1688 \mathrm{~cm}^{-1}$. Elemental Analysis \% experimental (\%calculated): C 45.94 (45.89), H 1.10 (1.01), N 8.41 (8.45).

\section{Conclusions}

In conclusion we have developed a new family of isophthalamides and dipicolinepamides receptors bearing various halogenated aromatic substituents. The results obtained in the solution studies by ${ }^{1} \mathrm{H}$ - and ${ }^{19} \mathrm{~F}-\mathrm{NMR}$ show that only receptors $\mathbf{L 5}$ and $\mathbf{L} \mathbf{6}$ bearing pentafluorophenyl rings as substituents have affinities for some of anions considered. In particular, in the case of $\mathbf{L 5}$ an interesting behaviour with the formation of a non-symmetric adduct was proposed and confirmed by theoretical calculations in the interaction with benzoate and dihydrogenophosphate. No halogen bonds appear to contribute to anion binding; however, the analysis of the crystal structures of the receptors demonstrate that the steric hindrance of the halogens might influences the accessibility of the isophtalamide or dipicoline amide $\mathrm{NHs}$ also in solution, thus modulating the affinity towards the anions which bind to the receptors via $\mathrm{H}$-bond and $\pi$ - $\pi$ interactions. We have also recently shown that only $\mathbf{L 5}$ and $\mathbf{L 6}$ which are able to bind anions can also work as synthetic anion transporters through lipid vesicles. ${ }^{30}$

\section{Conflicts of interest}

There are no conflicts to declare.

\section{Acknowledgements}

Financial support from MIUR (PRIN 2017 project 2017EKCS35) is gratefully acknowledged by C.C. G.P. and V.L.. C.C., V.L., F.I., S.M. thank Università degli Studi di Cagliari (FIR 2016-2019) and Fondazione di Sardegna (FdS Progetti Biennali di Ateneo, annualità 2018) for financial support. CC and RM would like to thank Laura Marongiu and Matteo Fois for participation to the experimental work.

\section{Notes and references}

‡ Crystal structures deposition numbers: 1995354-1995358.

1. V. Amendola, L. Fabbrizzi and L. Mosca, Chem. Soc. Rev., 2010, 39, 3889-3915.

2. P. A. Gale, E. N. W. Howe and X. Wu, Chem, 2016, 1, 351422.

3. P. A. Gale, E. N. W. Howe, X. Wu and M. J. Spooner, Coord. Chem. Rev., 2018, 375, 333-372.

4. Q. He, P. Tu and J. L. Sessler, Chem, 2018, 4, 46-93.

5. M. J. Langton, C. J. Serpell and P. D. Beer, Angew. Chem. Int. Ed., 2016, 55, 1974-1987.

6. M. P. Hughes and B. D. Smith, J. Org. Chem., 1997, 62, 4492-4499.

7. K. Kavallieratos, S. R. De Gala, D. J. Austin and R. H. Crabtree, J. Am. Chem. Soc., 1997, 119, 2325-2326.

8. G. W. Bates, P. A. Gale and M. E. Light, Chem. Comm., 2007, 2121-2123.

9. I. J. Bazany-Rodríguez, D. Martínez-Otero, J. BarrosoFlores, A. K. Yatsimirsky and A. Dorazco-González, Sensors and Act., B: Chemical, 2015, 221, 1348-1355.

$10 . \quad$ S. N. Berry, N. Busschaert, C. L. Frankling, D. Salter and P. A. Gale, Org. Biomol. Chem., 2015, 13, 3136-3143.

11. I. A. Carasel, C. R. Yamnitz, R. K. Winter and G. W. Gokel, J. Org. Chem., 2010, 75, 8112-8116.

12. S. J. Coles, J. G. Frey, P. A. Gale, M. B. Hursthouse, M. E. Light, K. Navakhun and G. L. Thomas, Chem. Comm., 2003, 5, 568-569.

13. J. Eckelmann, V. Saggiomo, S. Fischmann and U. Lüning, Beilst. J. Org. Chem., 2012, 8, 11-17.

14. N. Łukasik and E. Wagner-Wysiecka, Photochem. Photobiol. Sci., 2017, 16, 1570-1579.

15. L. Mao, W. Pan, Y. Fu, L. Chen, M. Xu, Y. Ren, W. Feng and L. Yuan, Org. Lett., 2017, 19, 18-21.

16. X. Wu, R. Liu, B. Sathyamoorthy, K. Yamato, G. Liang, L. Shen, S. Ma, D. K. Sukumaran, T. Szyperski, W. Fang, L. He, X. Chen and B. Gong, J. Am. Chem. Soc., 2015, 137, 58795882.

17. Y. Zhang, R. Cao, J. Shen, C. S. F. Detchou, Y. Zhong, H. Wang, S. Zou, Q. Huang, C. Lian, Q. Wang, J. Zhu and B. Gong, Org. Lett., 2018, 20, 1555-1558.

18. R. Montis, A. Bencini, S. J. Coles, L. Conti, L. Fusaro, P. A. Gale, C. Giorgi, P. N. Horton, V. Lippolis, L. K. Mapp and C. Caltagirone, Chem. Comm., 2019, 55, 2745-2748. 
19. G. Ciancaleoni, Phys. Chem. Chem. Phys., 2018, 20, 85068514.

20. L. C. Gilday, S. W. Robinson, T. A. Barendt, M. J. Langton, B. R. Mullaney and P. D. Beer, Chem. Rev., 2015, 115, 7118-7195.

21. R. Montis, M. Arca, M. C. Aragoni, A. Bauzá, F. Demartin, A. Frontera, F. Isaia and V. Lippolis, CrystEngComm, 2017, 19, 4401-4412.

22. G. Cavallo, P. Metrangolo, R. Milani, T. Pilati, A. Priimagi, G. Resnati and G. Terraneo, Chem. Rev., 2016, 116, 24782601.

23. R. Tepper and U. S. Schubert, Angew. Chem. - Int. Ed., 2018, 57, 6004-6016.

24. M. Giese, M. Albrecht and K. Rissanen, Chem. Rev., 2015, 115, 8867-8895.

25. D. Quiñonero, C. Garau, C. Rotger, A. Frontera, P. Ballester, A. Costa and P. M. Deyà, Angew. Chem. Int. Ed., 2002, 41, 3389-3392.

26. M. R. Battaglia, A. D. Buckingham, D. Neumark, R. K. Pierens and J. H. Williams, Mol. Phys., 1981, 43, 10151020.

27. H. Adams, J. L. Jimenez Blanco, G. Chessari, C. A. Hunter, C. M. R. Low, J. M. Sanderson and J. G. Vinter, Chem. - Eur. J., 2001, 7, 3494-3503.

28. M. J. Hynes, J. Chem. Soc., Dalton Trans., 1993, 311-312.

29. A. Casula, P. Begines, A. Bettoschi, J. G. FernandezBolaños, F. Isaia, V. Lippolis, Ó. López, G. Picci, M. Andrea Scorciapino and C. Caltagirone, Chem. Comm., 2017, 53, 11869-11872.

30. G. Picci, I. Carreira-Barral, D. Alonso-Carrillo, D. SanzGonzález, P. Fernández-López, M. García-Valverde, C. Caltagirone and R. Quesada, Supramol. Chem., 2019. 